single-dose ( $10 \mathrm{mg}$ base $/ \mathrm{kg}$ ) and triple-dose $(25 \mathrm{mg}$ base $/ \mathrm{kg})$ treatment. The mechanism is unknown, but treatment with antihistamines is reported to be ineffective.

The reported incidence of chloroquine-associated pruritus in Nigerians varies from 8 to $28 \%,{ }^{23}$ but we are unaware of any reported cases in Europeans. Although this side effect was mentioned in the 1940 s by Berliner et $a l,{ }^{4}$ it was seen only when the amount of chloroquine given was well in excess of the standard dosage for antimalarial treatment.

1 Ekpechi O, Okoro AN. A pattern of pruritis due to chloroquine. Arch Dermatol 1964;89:631-2.

2 Olantunde A. The practical and therapeutic implications of chloroquineinduced itching in tropical Africa. Afr $\mathcal{F}$ Med Med Sci 1977;6: $27-31$.

${ }^{3}$ Olantunde A, Obih PO. Use and misuse of 4-aminoquinoline antimalaria in tropical Africa and re-examination of itch reaction to these drugs. Trop Doct $1981 ; 11: 97-101$.

${ }^{4}$ Berliner RW, Earle DP, Taggart JV, et al. Studies on the chemotherapy of human malarias. VI: The physiological disposition, antimalarial activity, and toxicity of several derivatives of 4-aminoquinoline. $\mathrm{f}$ Clin Invest 1948;27,suppl:98-107.

(Accepted 24 August 1982)

Clinical Research Center, Kenya Medical Research Institute, Nairobi, Kenya

H C SPENCER, MD, MPH, senior scientist (also at Center for Infectious Diseases, Centers for Disease Control, Public Health Service, US Department of Health and Human Services)

The Wellcome Trust Research Laboratories, Nairobi, Kenya

N R POULTER, MB, MRCP, clinical lecturer (also honorary clinical lecturer, St Mary's Hospital, London)

J D LURY, SRN, research assistant

C J POULTER, SRN, research assistant

\section{Achalasia: presentation with stridor and a new form of treatment}

Achalasia is a fairly uncommon disorder resulting from abnormalities of the motor innervation of the lower oesophagus. Symptoms are usually intermittent dysphagia and malnutrition, chest pain, and infection. Patients with achalasia may, however, present with compression of the upper airway. ${ }^{1-3}$

\section{Case report}

An 87-year-old woman with no previous medical history of note was admitted to hospital with acute breathlessness. On examination the patient was severely unwell and dyspnoeic. Pulse was $150 / \mathrm{min}$, blood pressure $180 / 60$ $\mathrm{mm} \mathrm{Hg}$, and jugular vein pulse was raised at $6 \mathrm{~cm}$. Heart sounds were normal, and the apex beat was palpable in the anterior axillary line. Air entry was diminished over the right lung and stridor was present. A portable chest $x$-ray film (figure) showed a dilated gas-filled structure extending from the mediastinum to the level of the larynx. Indirect laryngoscopy was performed and a large retropharyngeal swelling at the level of the arytenoid cartilages was evident, pushing the larynx forward. During the procedure the patient's condition deteriorated further. As an emergency measure a cardiac needle was pushed into the mass and about $50 \mathrm{ml}$ of air was aspirated. The patient's condition improved dramatically. She then underwent rigid bronchoscopy, which showed no abnormality apart from copious secretions, which were aspirated.

An emergency barium swallow showed the oesophagus to be hugely dilated proximally with an apparent stricture about $11 \mathrm{~cm}$ from the cardia. At fibreoptic oesophagoscopy there was a large collection of food and fluid in the oesophagus but no stricture, and the endoscope passed readily through the cardia into the stomach. The appearances were characteristic of achalasia of the cardia and findings of further barium studies supported this diagnosis. It then became apparent that she had had dysphagia for some months and was unable to swallow liquids. Rider-Moeller bag dilatation of the lower sphincteric ring was therefore undertaken on two occasions. Initially, her general condition and dysphagia improved, but she subsequently developed bronchopneumonia and died eight weeks from the time of presentation.

At necropsy the respiratory system showed severe bronchopneumonia with patchy consolidation of both lower lobes. In the alimentary system the oesophagus was widely dilated in its upper two thirds and contained food and fluid. The lower third was narrowed and showed no evidence of ulceration or malignancy.

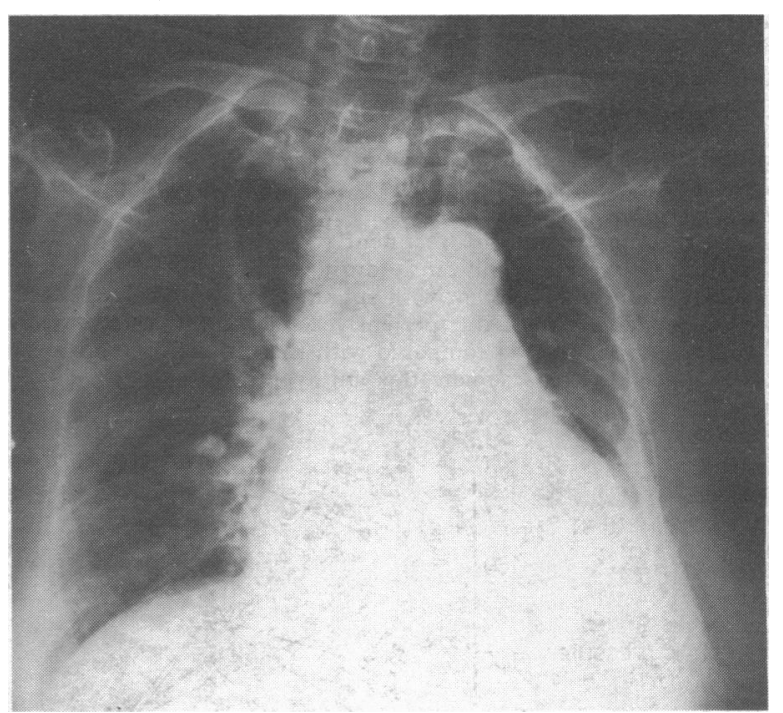

Chest $x$-ray film before decompression showing the dilated oesophagus and also shift of mediastinum to left.

\section{Comment}

McLean et al supplied an explanation of the mechanism wheretay the oesophagus becomes dilated to the extent that it impinges on the larynx and is able to distort the posterior membranous portion of the trachea, giving rise to features of obstruction of the upper airway They contend that the cricopharyngeal muscle that normally prevents air swallowing may malfunction to the extent that air swallowing $\&$ facilitated while escape of swallowed air is prevented. Consequentlys the oesophagus dilates hugely and compresses neighbouring structurest depending on the extent of oesophageal dilatation there may also signs of obstruction of the thoracic inlet. Decompression of the oesophagus results in a dramatic relief of symptoms. Previously thes has been achieved by emergency oesophagoscopy. ${ }^{1}$

Treatment by needle aspiration of the oesophagus has not previous been described and may be lifesaving if emergency oesophagoscopy not available.

1 McLean RDW, Stewart CJ, Whyte DGC. Acute thoracic inlet obstruction in achalasia of the oesophagus. Thorax 1976;31:456-9.

Bello CT, Lewin JR, Norris CM, Farrar GE Jr. Achalasia (cardiospasm report of a case with extreme and unusual manifestations. Ann Inte Med 1950;32:1184-90.

${ }^{3}$ Giustra PE, Killoran PJ, Wasgatt WN. Acute stridor in achalasia of tise esophagus (cardiospasm). Am $\mathcal{F}$ Gastroenterol 1973;60:160-4.

(Accepted 16 September 1982)

Peterborough District Hospital, Peterborough PE3 6DA

C R EVANS, MB, BS, senior house physician

R CAWOOD, MB, FRCS, consultant ear, nose, and throat surgeon

$M$ W DRONFIELD, DM, MRCP, consultant physician

I P F MUNGALL, MD, MRCP, consultant physician

\section{Corrections}

Mid-arm circumference as simple means of identifying malnutrition in Crohn's disease

An error occurred in this paper by Dr A D Harries and others (6 November $\mathrm{p}$ 1317). In the table under the side heading serum prealbumin concentration number with less than $20 \mathrm{mg} / \mathrm{l}$ should have read number with less than $20 \mathrm{G}$ $\mathrm{mg} / \mathrm{l}$.

Treatment of digoxin overdose with antigen-binding fragments of digoxin-specific antibodies

We regret that an error occurred in the short report by A Rokzovec and D Coltart. The serum concentrations of digoxin should have been expressed as $\mu \mathrm{g} / \mathrm{l}$ and not as $\mathrm{g} / \mathrm{l}$. 